\title{
Retraction Note: Ocean coastal temperature front based on sensor network and research on the new teaching mode in colleges and universities
}

\section{Dongmei Liu ${ }^{1}$}

Published online: 4 November 2021

c) Saudi Society for Geosciences 2021

Retraction Note: Arabian Journal of Geosciences (2021) 14: 1511 https://doi.org/10.1007/s12517-021-07896-5

The Editor-in-Chief and the Publisher have retracted this article because the content of this article is nonsensical. The peer review process was not carried out in accordance with the Publisher's peer review policy. The author has not responded to correspondence regarding this retraction.

The original article can be found online at https://doi.org/10.1007/ s12517-021-07896-5.

Dongmei Liu

qwe12320210428@163.com

1 The Library of Changchun Normal University,

Changchun 130032, Jilin, China 